\title{
REKONSTRUKSI AKAD MURABAHAH (STUDI AKAD MURABAHAH DI BMT SM NU PEKALONGAN)
}

\author{
Oleh: Baidhowi \\ baidhowi.3579@gmail.com
}

\begin{abstract}
Abstrack
This research tries to answer the question on how the implementation of akad murabahah (murabahah agreement) in BMT NU Pekalongan? Is there any requirement which possibly violating the agreement? And how is the solution so that the agreement complies with syari'ah? This is a descriptive qualitative research. Both primary and secondary data were collected through documentation. Data were analyzed in three steps: reduction, display and verification. Result shows that: 1. There are two kinds of agreement of murabahah in BMT NU Pekalongan: with wakalah and without wakalah. The implementation of murabahah in BMT NUPekalongan is complicated in its contract. There are at least four kinds of agreements, namely: murabahah loan, rent agreement, ijarah contract, and loan. 2. In the murabahah agreement with wakalah, there is some requirement which is not complied with shari'ah namely fake transaction. 3. There are two alternative of agreement reconstruction so the requirements are complied with shari'ah.
\end{abstract}

Keywords: murabahah, agreement, BMT

\section{A. Latar Belakang}

Hadirnya perbankan syariah dan bank syariah di Indonesia, merupakan bukti bahwa Islam telah memberikan petunjuk bagi manusia dalam melakukan berbagai aktivitas yang terkait cakupan ekonomi. Beragam produk serta layanan jasa perbankan yang beragam dengan skema keuangan yang lebih bervariatif, perbankan syariah menjadi alternatif sistem perbankan yang kredibel dan dapat diminati oleh seluruh golongan masyarakat indonesia tanpa terkecuali (http://www.bi.go.id/web/id/Perbankan/perbankan+syariah /).

Bank Syariah sebagai intermediary, berdiri sebagai badan hukum nyata dari implementasi dual banking system pada perbankan nasional. Di Indonesia, bank syariah dikukuhkan 
menjadi hukum positif dalam Undang-undang Nomor 21 tahun 2008 tentang Perbankan Syariah setelah sebelumnya belum diakui pada Undang -undang No 7 tahun 1992 tentang perbankan dan diamandemen dengan Undang-undang Nomor 10 Tahun 1998 tentang Perubahan Undang-undang Nomor 7 tahun 1992 tentang perbankan.

Islam mengajarkan kepada pemeluknya untuk mencari harta dengan segala cara asalkan mengikuti rmbu-rambu yangada, rambu-rambu itu antara lain mencari yang halal lagi baik, tidak dengan batil, tidak berlebih-lebihan,/ melampaui batas, tidak didzalimi maupun mendzalimi, menjauhkan diri dari unsur riba, maisir (perjudian dan Intended speculation) dan gharar (Muhammad Syafi'i Antonio, 2007: 12).

Dalam al-Qur'an ditegaskan untuk menjauhi segala hal yang bertentanga dengan riba, maisir dan gharar. Surat ar-Rum ayat 39 ditegaskan:

"dan suatu riba (tambahan) yang kamu berikan agar dia bertambah pada harta manusia, maka tidak bertambah dalam pandangan Allah. Dan apa yang kamu berikan berupa zakat yang kamu maksudkan untuk mencapai keridhaan Allah, maka (yang berbuat demikian) itulah orang-orang yang melipatgandakan (pahalanya). (QS ar-Rum: 39)

Pada prinsipnya, produk syariah didukung dengan lahirnya UU No 21 tahun 2008, sehingga telah jelas adanya pengakuan dari hukum positif bahwa prinsip syariah dapat diterapkan secara menyeluruh. Selain poengeluaran UU Perbankan Syariah, Bank Indonesia telah menetapkan peraturan yang terkait dengan dengan kajian yaitu PBI No.10/17/PBI/2008 tentang Produk Bank Syariah dan Unit Usaha syariah, PBI No. 13/13/PBI/2011 tentang penilaian Kualitas Aktiva bagi bank Umum Syariah dan Unit Usaha Syariah dan SK Dir Bank Indonesia Nomor 27/162/KEP/DIR tanggal 31 Maret 1995 tentang Kewajiban Penyusunan dan Pelaksanaan Kebijaksanaan Perkreditan bank bagi bank Umum.

Dalam agama Islam, hubungan antar sesama manusia di bahas dalam ilmu fiqh ( baca : fiqh muamalat), misalnya hubungan antara 2 pihak yang melakukan jual beli dengan akad murabahah. Secara sederhana akad murabahah berarti perikatan jual-beli barang dimana pembeli mengetahui jumlah keuntungan yang diambil oleh si penjual.Dalam konteks 
perbankan syariah saat ini, akad murabahah merupakan salah satu akad utama, atau bahkan paling dominan, yang sering digunakan oleh para praktisi perbankan syariah dalam menyediakan kebutuhan pembiayaan nasabah.

Dasar hukum murabahah menurut ijma' para ulama adalah umat Islam telah berkonsesus tentang keabsahan jual beli, karena manusia sebagai anggota masyarakat selalu membutuhkan apa yang dihasilkan dan dimiliki orang lain, oleh karena itu jual beli adalah salah satu jalan untuk mendapatkannya secara sah, dengan demikian maka mudahlah bagi setiap individu untuk memenuhi kebutuhannya (Muhammad, 2005:23). Lebih khusus lagi Dewan Syariah Nasioanl MUI mengeluarkan Fatwa DSN Merujuk Fatwa DSN No.04/DSN-MUI/IV/2000 tanggal 01 April 2000 tentang Murabahah.

Berdasar pada catatan laporan Dewan pengawas Syariah, pada prinsipnya produk-produk pembiayaan murabahah adalah sesuai syar'i namun harus diakui, masing sering ditemukan adanya pemaksaan akad pada suatu kontrak perjanjian, atau penerapan akad murabahah wal wakalah. Misalnya, akad yang seharusnya untuk modal kerja (mudharabah atau musyarakah) dipaksa ke akad jual beli (murabahah) (Muhammad, UII Pres: 120). Hal ini juga yang terjadi pada Perjanjian yang di buat antara nasabah dengan BMT NU Pekalongan, selain sangat sederhana perjanjiannya, nampak akad murabahahnya belum jelas antara harga dan marginnya. Oleh sebab itu peneliti tertarik untuk mengkaji produk murabahah yang disertai dengan ijarah muntahiya bi at-tamlik tersebut.

\section{B. Rumusan Permasalahan}

Dalam konteks ini penulis menfokuskan pada permasalahan:

1. Bagaimana penerapan akad murabahah di BMT NU Pekalongan?

2. Apakah dalam penerapan akad tersebut terdapat klausulklausul yang dapat merusak akad?

3. Apa solusi agar akad tersebut dapat sesuai dengan syari'ah? 


\section{Tinjauan Pustaka}

\section{Rekonstruksi}

Dalam Kamus Besar Bahasa Indonesia, makna rekonstruksi adalah pengembalian seperti semula, penyusunan (penggambaran) kembali. menurut Yusuf Qardhawi rekonstruksi itu mencakup tiga poin penting, yaitu pertama, memelihara inti bangunan asal dengan tetap menjaga watak dan karakteristiknya. Kedua, memperbaiki hal-hal yang telah runtuh dan memperkuat kembali sendi- sendi yang telah lemah. Ketiga, memasukkan beberapa pembaharuan tanpa mengubah watak dan karakteristik aslinya.

Dari sini dapat dipahami bahwa pembaharuan bukanlah menampilkan sesuatu yang benar-benar baru, namun lebih tepatnya merekonstruksi kembali kemudian menerapkannya dengan realita saat ini.Berdasarkan uraian diatas maka dapat peneliti simpulkan maksud rekonstruksi dalam penelitian ini adalah mengembalikan pembaharuan system atau bentuk. Berhubungan dengan rekonstruksi pelakanaan akad murabahah, sehingga amksud dan prakteknya selaras dengan apa yang ditentukan dalam akad murabahah.

\section{Pengertian Murabah}

Dari segi bahasa, Murabahah atau murabahah asal kata darii masdar baraha yang berarti:sesuatu yang tumbuh dalam, maka bagi orang Arab seseorang itu dianggap untung jika aset dagangannya tumbuh/bertambah, hal ini senada dengan ayat Al-qur'an al-Baqarah: 16 artinya:maka tidaklah bertambah(untung) perniagaan mereka.

Para ahli bahasa Arab (Diantaranya Ibnu Mandhzur) mengomentari bahwa: dikatakan murabahah (saling meguntungkan) karena masing-masing dari pihak pembeli dan pihak penjual saling menguntungkan, si penjual bertambah modal dagangannya dan si pembeli bertambah aset usahanya.

Sedangkan secara Termonologi, pengertian murabah menurut ulama syariah klasik (Ulama Hanafiyah, Malikiyah, Syafi'iyah dan Hambali) penulis menemukan kesepakatan mereka bahwa murabahah terdiri dari dua unsur yang utama; Pertama, harga pokok ditambah biaya- 
biaya -cost-yang timbul dari pembelian/ pengadaan barang yang pasti, kecuali biaya dilakukan secara estimasi, hal ini hanya Ulama Hanafiyah dan Syafi'iyah yang membolehkan biaya estimasi asalkan dirinci dengan jelas.Dan semua Ulama sepakat agar pemisahan antara harga pokok dan biaya-biaya. kedua, keuntungan.Karena murabahah adalah system jual beli bersifat amanah, maka seharusnya harga pokok awal dan tambahan/ keuntungan (margin) transparan. Dari kesimpulan diatas, penulis mencoba memberikan pengertian murabahah menurut pandangan klasik adalah:"Transaksi jual-beli dengan harga pokok include biaya-biaya- ditambah dengan margin secara transparan sesuai kesepakatan bersama antara pembeli dan penjual"

Secara kontemporer Sistem jual-beli murabahah yang diterapkan/ diaplikasikan banyak oleh lembagakeuangan syariah sekarang ini atau murabahah dengan pesanan pembelian, adalah hasil inovasi rekonstruksi murabahah yang dipelopori dan disosialisasikan pada lembaga keuangan islam oleh DR.Sami Hasan Hamud pada saat mempertahankan desertasinya yang diajukan pada

Universitas Al-Azhar, Mesir (Sami Hamud:192). Beliau menguraikan pengertiannya sebagai berikut; "suatu kesapakatan antara pihak bank dan nasabah,agar bank menyediakan barang yang dibutuhkan oleh nasabah, dan nasabah akan mebelinya serta bank menjual kepadanya dengan system pembayaran tunai atau tunda, yang sudah ditentukan harga pokok pembelian ditambah keuntungan (margin) terlebih dahulu."

Lahirnya inovasi baru ini sesungguhnya DRS ami terinspirasi dari karyapara Ulama Klasik juga, sekalipun istilah yang dipakai berbeda, hal itu dapat ditelusuri dari karya-karya mereka diantaranya; Kitab Mabsut karya Imam Assarkhasi, dijelaskan bahwa Muhammad bin Hasan Asysyaibani dalam kitab tersebut menguraikan karakteristik murabahah, yaitu:

a. Jenis murabahah ini cocok untuk properti, antara pemesan dan pihak yang diberi pesanan harus sepakat dalam menentukan harga pokok property dan tambahan/keuntungan (margin) sewaktu perjanjian. 
b. perjanjian dalam murabahah jenis ini bukanlah suatu keharusan, artinya pemesan tidak terikat walaupun sudah memesan barang, pemesan dapat menerima atau membatalkan barang tersebut.

c. Keharusan adanya ijab (permintaan dari pemesan) dan qabul (persetujuan atas permintaan dari yang diberi pesanan).

Demikian juga di kitab Al-Umm karya Imam Syafi'i, beliau menguraikan karakteristikmurabahah,diantaranya:

a) Boleh bagi pemesan/nasabah menentukan spesifikasi pesanannya.

b) terjadi kesepakatan dalam penentuan keuntungan (margin) pada saat perjanjian.

c) Penentuan besar kecilnya keuntungan (margin) berdasarkan kelihaian yang diberi pesanan dalam meyediakan pesanan sesuai spesifikasi yang diminta, kualitas pesanan dan kemampuannya memperoleh dengan harga yang relative murah.

d) Sistem pembayaran pemesan (cash atau cicil) jadi patokan dalam penentuan keuntungan dan produsen agar dapat memperoleh barang yang lebih berkualitas dan biaya-biaya pengadaannya dapat ditekan.

e) Imam Syafi'I menguraikan alas an ketidak terikatnya pemesan disebabkan janji walaupun sudah memesan barang (pemesan dapat menerima atau membatalkan barang tersebut) disaat perjanjian, yaitu: menghindari peraktek jual-beli barang/ komoditas apapun yang belum dimiliki oleh penjual dan unsure spekulasinya.

Sama halnya pada referensi para Ulama Malikiyyah seperti:At-Taaj karya Ibnu Qasim, Syareh Al-kabir karya Addardir, Mawahibal-Jalil karya Ibnu Abdurrahman. Begitu juga pada referensi Ulama Hanafiyah, yaitu Ilamul muwaqqi'inkarya Ibnu Qayyim.

Sedangkan Merujuk Fatwa DSN No.04/DSNMUI/IV/2000 tanggal 01 April 2000 tentang Murabahah, dinyatakan bahwa: "Murabahah adalah menjual suatu barang dengan menegaskan harga belinya kepada pembeli dan pembeli membayarnya dengan harga yang lebih sebagai laba"

Dari semua referensi di atas dapat ditarik kesimpulan bahwa di antara karakteristik murabahah itu; 
a. Bagi masing-masing yang melakukan transaksi-baik pihak pemesan maupun yang diberi pesananmemiliki hak khiyar (memilih) membeli atau tidak setelah barang pesanan dimiliki oleh yang dipesan.

b. Tidak ada unsur keterikatan dalam perjanjian dan janji, seandainya sepakat kedua untuk saling mengikat maka jual-beli murabahah menjadi rusak.

c. Boleh membuat kesepakatan pada saat kontrak perjanjian dalam menentukan: jenis barangnya, sumbernya, harganya, spespikasi khususnya, dan memberikan kebebasan penuh bagi yang diberi pesanan dalam pengadaannya.

d. Begitu juga boleh menentukan keuntungan

(margin) dan tenggang waktu disaat kontrak perjanjian.

e. Sistem pembayaran dalam murabahah dapat dilakukan dengan cara tunai/cash atau tunda/cicil.

\section{Rukun dan syarat-syarat dalam akad pembiayaan murabahah}

Berkaitan dengan rukun dan syarat-syarat akad murabahah dalam kaidah muamalat Islam adalah sebagai berikut :

Rukun akad murabahah:

1. Ada penjual (bai')

2. Ada pembeli (musytari)

3. Ada barang (mabi')

4. Sigat dalam bentuk ijab qabul.

Penjual dalam hal ini adalah pihak bank, yaitu bank yang berprinsip syariah yang akan memberikan pembiayaan. Pembeli (musytari) adalah nasabah yang akan menerima pembiayaan. Barang (mabi) adalah barang yang dibutuhkan oleh nasabah dan disebut obyek akad. Sedangkan sighat dalam bentuk ijab qabul. Ijab adalah perkataan penjual, sedangkan qabul merupakan perkataan pembeli.

Adapun syarat-syarat dalam akad murabahah adalah :

a. Pembeli (musytari) hendaklah betul-betul mengetahui modal sebenarnya dari suatu barang yang hendak dibeli. 
b. Penjual dan pembeli hendaklah setuju dengan kadar hitungan atau tambahan harga yang ditetapkan tanpa ada sedikitpun paksaan.

c. barang yang dijual belikan bukanlah barang ribawi (semua barang yang dapat mendatangkan riba).

d. Sekiranya barang tersebut telah dibeli dari pihak lain, jual beli yang pertama itu harus sah menurut perundang-undangan Islam (Gemala Dewi,2008: 89).

\section{Pembentukan akad Pembiayaan Murabahah}

Yang dimaksud dengan akad adalah suatu perikatan antara ijab dan qabul dengan cara-cara yang dibenarkan oleh syara', yang menetapkan adanya akibat hukum pada obyeknya. Ijab adalah pernyataan pihak pertama, sedangkan qabul adalah pernyataan pihak kedua untuk menerimanya. Ijab dan qabul ini dilakukan dengan maksud untuk menunjukkan adanya sukarela timbal balik terhadap akad yang dilakukan oleh dua pihak yang bersangkutan. Agar suatu akad dipandang terjadi harus diperhatikan rukun dan syarat-syaratnya sebagaimana telah diuraikan diatas.

Penjual (bai') dan pembeli (musytari) adalah sebagai pendukung hak. Di dalam fiqih Islam pendukung hak adalah manusia yang memiliki berbagai macam hak dan kewajiban kodrati atas pemberian Allah (Ahmad Azhar Basyir, 2000: 27). Untuk dapat melakukan perbuatan hukum dalam bidang muamalat sangat tergantung kepada kecakapan menggunakan haknya kepada orang lain. Manusia dipandang telah mempunyai kecakapan hukum yang sempurna apabila telah akil balig artinya tidak saja ditentukan oleh batasan umur saja tetapi juga ditekankan pada adanya kematangan pertimbangan akal (rusyd).

Sedangkan di dalam hukum perdata yang disebut dengan subyek hukum adalah pendukung hak dan kewajiban yang terdiri dari orang (natuurlijk person) dan badan Hukum (recht person). Pada asasnya semua orang dapat mempunyai hak dan biasanya juga cakap melakukan perbuatan hukum tetapi undang-undang menetapkan golongan orang-orang tertentu dianggap tidak cakap 
melakukan perbuatan hukum. (Pasal 330 BW).Badan hukum ini oleh undang-undang dianggap sebagai manuisa yang mempunyai hak dan kewajiban hukum. Yang dimaksud dengan Badan Hukum adalah sekelompok orang yang menggabungkan diri dalam perkumpulan dan merupakan suatu kasatuan yang berdiri sendiri dan mempunyai tujuan dan kekayaan sendiri, pengurusnya melakukan perbuatan hukum (Bachsan Mustafa,t.th: 13).

Dilihat dari yang mengurus dan mengatur badan hukum ini dibagi dalam dua golongan:

1. Badan Hukum Privat dibentuk dan diatur oleh hukum privat seperti yayasan, koperasi, Perseroan Terbatas.

2. Badan Hukum Publik dibetuk dan diatur oleh hukum publik seperti negara, propinsi.

Barang (mabi') merupakan obyek akad dalam hal ini adalah barang yang dibutuhkan oleh nasabah. Agar sesuatu akad dipandang sah maka obyeknya memerlukan syarat-syarat sebagi berikut:

1. Obyek akad telah ada pada waktu akad diadakan, barang yang belum wujud tidak dapat menjadi obyek akad, menurut pendapat kebanyakan fukaha sebab hukum dan akibat akad tidak mungkin bergantung pada sesuatu yang belum wujud. Oleh karenanya, akad salam, murabahah (pesan barang) yang manfaatnya belum dinikmati, dipandang sebagai pengecualian ketentuan umum tersebut.

2. Obyek akad dapat ditentukan dan diketahui oleh kedua belah pihak yang melakukan akad.

3. Obyek akad dapat diserahkan pada waktu akad terjadi hal ini tidak berarti harus dapat diserahkan seketika, yang dimaksudkan adalah pada saat yang ditentukan dalam akad, obyek akad dapat diserahkan karena memang benar-benar ada dibawah kekuasaan yang sah pihak yang bersangkutan.

\section{Asas- Asas Akad}

Dalam hukum perjanjian menurut KUHPerdata mengenal asas kebebesan berkontrak, asas personalitas dan asas itikad baik, sedangkan dalam hukum adat mengenal asas terang, tunai dan riil. Demikian juga 
Hukum Islam dalam perjanjian, mengenal asas sebagai berikut: a. Al-Hurriyah (bebas membuat suatu perjanjian atau akad), b. Al- Musawah (peramaan atau kesetaraan), c. Al-adalah (keadilan) d. Al-Ridha (kerelaan) semua transaksi harus dilakukan atas dasar kerelaan antara masing-masing pihak, tidak boleh ada unsur paksaan, tekanan dan penipuan. E. Ash-shidiq (kebenaran/ kejujuran), f. Al-kitabah (tertulis), setiap akad hendaknya dilakukan secara tertulis demi kepentingan pembuktian jika dikemudian hari terjadi sengketa (Bagya Agung Prabowo, 2012: 50-51).

\section{Jaminan dalam Murabahah}

Dhomman (jaminan) dalam murabahah diperbolehkan agar musytari (pembeli) serius dengan pesanan $B a^{\prime} i$ (penjual) dapat meminta musytari untuk menyediakan dhomman yang dapat dipegang. Setelah membahas tentang akad jual beli antara bank dengan pemasok barang, akad murabahah antara bank dengan nasabah dan pengikatan jaminan atas benda yang menjadi obyek dalam akad murabahah, maka kontruksi hukum akad jual beli pada pembiayaan murabahah tersusun sebagai berikut:

1. Dilakukan akad jual beli antara bank dengan pemasok barang, dalam hal ini bank membeli barang kepada pemasok dan dibayar dengan tunai, apabila dalam pembelian barang bank menunjuk nasabah atau orang lain atas nama bank, maka menggunakan prinsip wakalah, sampai barang sah menjadi milik bank.

2. Dilakukan akad murabahah antara bank dengan nasabah, bank menjual barang kepada nasabah dengan harga jual yaitu harga pokok ditambah margin keuntungan yang telah disepakati, nasabah membayar secara tangguh sesuai dengan perjanjian, akad ini merupakan perjanjian pokok yang menimbulkan perjanjian hutang piutang.

Dilakukan perjanjian pengikatan jaminan antara bank dengan nasabah, perjanjian ini merupakan perjanjian ikutan (assesoir) dari suatu perjanjian pokok dalam hal ini 
akad murabahah yang menimbulkan kewajiban para pihak untuk memenuhi prestasi, yang dapat dinilai dengan uang

\section{Metodologi}

2.1. Jenis Penelitian

Jenis penelitian yang dilakukan menggunakan metode kualitatif dengan berbasis pendekatan deskriptif. Penelitian yang bersifat deskriptif adalah penelitian yang bertujuan menggambarkan secara tepat sifat suatu individu, keadaan, gejala atau kelompok tertentu atau untuk menentukan frekuensi suatu gejala (Sri Mamudji, 2005: 4). Peneliti akan mengkaji kesesuaian pelaksanaan akad murabahah di BMT NU Pekalongan dengan fatwa DSN No.04/DSN-MUI/IV/2000 tentang Murabahah serta peratutan yang terkait.

2.2. Sumber dan jenis data

Peneliti akan menggunakan dua jenis data, yaitu data primer dan data sekunder (Soerdjono Soekamto dan sri mamudji (Soerdjono Soekamto dan sri mamudji,1994: 37). Pengumpulan data primer akan dilakukan peneliti dengan mengumpulkan dokumen yang terkait dengan akad murabahah oleh BMT SM NU pekalongan.

Data sekunder sebagai sumber data utama dalam penelitian normatif akan peneliti gunakan untuk mempelajari serta memahami peraturan perundangundangan serta fatwa yang berlaku bagi penerapan akad murabahah di BMT NU Pekalongan. Data sekunder yang penliti jadikan rujukan terdiri dari bahan hukum primer, sekunder dan tersier sebagai berikut:

1. Bahan Hukum Primer: yaitu bahan hukum yang mempunyai kekuatan mengikat berupa peraturan per undang- undangan Republik Indonesia Nomor 21 tahun 2008 tentang Perbankan Syariah, PBI No.10/17/PBI/2008 tentang Produk Bank Syariah dan Unit Usaha Syariah, dan fatwa DSN No.04/DSNMUI/IV/2000 tanggal 01 April 2000 tentang Murabahah.

2. Bahan hukum sekunder, yaitu bahan hukum yang erat kaitannya dengan bahan hukum primer dan dapat membantu menganalisa, memahami dan 
menjelaskan bahan hukum primer. Antara lain doktrin yang ada dalam buku-buku, laporan penelitian, penelusuran internet, artikel ilmiah, jurnal, hasil seminar, surat kabar dan makalah yang terkait dengan topik penelitian (Soerjono Soekanto,2010: 32)

2.3. Teknik Pengumpulan data

Adapun teknik pengumpulan data yang akan dilakukan dalam penelitian ini sebagai berikut:

1. Dokumentasi, dengan mengumpulkan data berupa laporan tahunan BMT NU Pekalongan tahun 2015 khususnya terkait dengan akad Murabahah disertai IMBT.

2. Studi Literatur, dengan melakukan pengkajian literatur undang- undangan Republik Indonesia Nomor 21 tahun 2008 tentang Perbankan Syariah, PBI No.10/17/PBI/2008 tentang Produk Bank Syariah dan Unit Usaha Syariah, dan fatwa DSN No.04/DSNMUI/IV/2000 tanggal 01 April 2000 tentang Murabahah, buku-buku terkait, fiqih muamalah dan referesni terkait.

\subsection{Analisis data}

Metode analisi yang digunakan dalam penelitian ini adalah menggunakan konsep Miles dan Hubermas. Dalam konsep Miles dan Hubermas sebagaimana yang dikutip oleh Sugiyono (2010: 250-255), dikemukakan bahwa terdapat tiga aktifiyas analisis data. Aktivitas pertama yaitu data reduction, sebuah aktivitas merangkum sehingga memudahkan pengumpulan data. Aktivitas kedua yaitu data display, sebuah aktivitas menyajikan data agar terorganisasikan dan mudah dipahami. Aktivitas ketiga yaitu conclusion drawing/verification, sebuah aktivitas penarikan kesimpulan dan verifikasi berdasarkan buktibukti data yang telah dikumpulkan

2.5. Uji kredibiltas data

Pengujian kredibiltas data dimaksudkan untuk memastikan tidak terdapat perbedaan antara hal-hal yang dilaporkan oleh peneliti dengan kenyataan sesungguhnya yang terjadi di lapangan dan dalam penelitian ini, cara-cara 
yang digunakan adalah sebaia berikut Sugiyono, 2010: 268270);

1. Meningaikatkan ketekunan, yaitu melakukan pengamatan secara lebih cermat dan berkesinambungan

2. Triangulasi, yaitu melakukan pengecekan data dari berbagai sumber dengan berbagai cara dan berbagai waktu

3. Menggunakan bahan referensi, yaitu menggunakan referensi-referensi terkait untuk membuktikan data yang telah ditemukan dalam penelitian

4. Menggunakan membercheck, yaitu melakukan pengecekan data yang diperoleh peneliti kepada pemberi data.

\section{E. Hasil Dan Pembahasan}

Pelaksanaan Akad Murabahah di BMT Syirkah Muawanah Nahdlatul Ulama Pekalongan. Akad murabahah antara BMT dan nasabah dilakukan sebagai berikut; akad yang dimaksud adalah Akad Pinjaman-Murabahah Nomor 15.106.03.00133. pada klausul pasal 1 menyatakan bahwa BMT menyetujui pembiayaan kepada pihak II sebesar Rp. 150. 000.000. dalam jangka waktu 6 bulan dengan angsuran Rp. 3.750.000,- dimulai sejak ditandatangani perjanjian. Pasal 2 cara pencairan pinjaman, point b; menyatakan bahwa Anggota/ calon anggota telah menandatangani perjanjian ini dan perjanjian lain yang dinyatakan oleh BMTSM NU Kota Pekalongan. Demikian juga Pada pasal 4 point 2) menyatakan "dalam hal pihak II (anggota/ calon anggota) dinyatakan cidera janji sebagaimana dinyatakan dalam ayat satu pasal 4 perjanjian ini, maka pihak II (anggota/ calon anggota) memberi kuasa kepada pihak I (BMT NU Kota Pekalongan) untuk menjual barang berupa: BPKB Tahun No. Pol: No Mesin; atas nama; alamat. Sertifikat hak Milik Nomor 133, luas $104 \mathrm{~m} 2$ atas nama Drs. Henison MM alamat Poncol guna membayar lunas kewajiban pihak II (anggota/ calon anggota) pada pijak I (BMT NU Kota Pekalongan).

Selain Akad Pinjaman-Murabahah, dokumen yang lain adalah akad Sewa Menyewa. Pada akad ini inti perjanjian 
adalah menyatakan bahwa pihak I menyewakan kepada Pihak II barang-barang yang tersebut pada akad murabahah tersebut di atas dengan biaya sewa (ujroh) sebesar Rp. 1.050.000,dengan jangka waktu 12 bulan. Dimulai sejak ditanda tangani. Tanggal dimulai perjanjian baik akad Pinjaman Murabahah maupun Akad Sewa Menyewa adalah tanggal 14 Oktober 2014.

Dokumen-dokumen perjanjian yang lain adalah Akad Ijaroh Muntahiah Bittamlik Murokkab dan Perjanjian Pinjaman. Pada perjanjian ijaroh isi intinya Pihak II menjual kepada pihak I berupa barang yang tersebut pada akad pinjaman-murabahah dengan harga Rp. 150.000.000,-. Sedangkan dokumen Perjanjian Pinjaman berisi 16 pasal, Diantara pasal 1 menyatakan bahwa BMT NU memberikan fasilitas Pinjaman kepada Pihak II sebesar Rp. 150.000.000,- untuk jangka 6 bulan dengan bagi hasil/ margin sebesar Rp. 3.750 .000 per bulan sejak ditanda tanganinya perjanjian (14 Oktober 2014) dan berakhir tanggal 14 oktober 2015.

\section{PEMBAHASAN;}

1. Pelaksanaan Akad Murabahah di BMT Syirkah Muawanah Nahdlatul Ulama Pekalongan.

Ketentuan adanya rukun dari sebuah akad tidak terlepas oleh adanya syarat- syarat yang harus dipenuhi agar tidak keluar dari ketentuan-ketentuan syariah. Adapun analisis dari syarat rukun dari pelaksanaan dari akad murabahah pada pembiayaan modal kerja di BMT Syirkah Muawanah Nahdlatul Ulama Pekalongan sebagai berikut:

Pelaksanaan akad murabahah pada pembiayaan modal kerja pada BMT Syirkah Muawanah Nahdlatul Ulama Pekalongan dilihat dari beberapa segi diantaranya:

Dokumen perjanjian yang menyertai akad murabahah ini ada sejumlah 4 macam. sehingga menjadikan ambigu (kabur). Yakni: Akad Pinjaman-Murabahah, Akad Sewa Menyewa, Akad Ijaroh Muntahia Bittamlik Murakkabah, dan Perjanjian Pinjaman.

Kekaburan ini dapat dilihat dari kesesuaian antara Kop Perjanjian dengan isinya. Semisal pada kop perjanjian "Akad Pinjaman Murabahah" dalam akad ini, lebih menekankan pada aspek pinjaman dibandingkan dengan subtansi murabahahnya. Merujuk Fatwa DSN No.04/DSN- 
MUI/IV/2000 tanggal 01 April 2000 tentang Murabahah, dinyatakan bahwa: "Murabahah adalah menjual suatu barang dengan menegaskan harga belinya kepada pembeli dan pembeli membayarnya dengan harga yang lebih sebagai laba". Pada akad ini pihak BMT menyatakan memberikan fasilitas pinjaman dan ketentuan marginnya. Selain itu ada klausul yang menyatakan memberikan kuasa penjualan terhadap barang jaminan dari pihak II. Kekurangan pada akad ini adalah tidak dilengkapi "akad wakalah" kepada pihak II untuk menyediakan barang yang dibutuhkan yang sesungguhnya dipersyaratkan pada akad Murabahah.Yakni hakikat dari barang yang dibutuhkan nasabah aalah sah milik BMT. Sehingga terkesan akad ini hanya berisi pinjaman dan besaran pengembalian pinjaman (bunga) serta barang jaminan sebagai penguat pihak BMT untuk memberikan pinjaman. Adapun mengenai barang sebagai objek jual beli tidak nampak secara nyata telah dimiliki oleh BMT.

Demikian juga pada kop surat perjanjian "Akad Sewa Menyewa" yang menyatakan bahwa Pihak II (pemohon pinjaman) telah menyewa barang-barang yang dijaminkan pada pihak I dan harus membayar uang sewa yang sudah ditentukan yakni sebesar 1.050.000/ perbulan. Akad ini juga mengandung pertanyaan. Mengapa pihak II harus menyewa kepada pihak I yang sesungguhnya barang jaminan tersebut merupakan miliknya sendiri.

Pada kop surat "Akad Ijaroh muntahiyah bittamlik murokkab" juga mengandung permasalahan, yakni berisi bahwa pihak II menjual kepada pihak Pihak I (BMT) berupa barang yang sesungguhnya menjadi jaminan (yang telah disebutkan pada 'akad pinjaman Murabahah"). Selanjutnya Pihak I membeli barang tersebut dengan harga yang disepakati yakni jumlah besaran pinjaman yang termaktub dalam "Akad Pinjaman Murabahah".

Dokumen yang keempat adalah perjanjian pinjaman yang berisi bahwa pihak I menyediakan pinjaman dan pihak II memberikan jaminan dan harus memberikan margin/imbalan yang sudah ditentukan. Hal ini nampak menegaskan bahwa antara pihak I dan Pihak II telah terjadi kesepakatan pinjam meminjam dan ada tambahan. Yang oleh islam tambahan ini termasuk dalam kategori riba. 
Selain itu Mekanisme akad murabahah pada produk pembiayaan modal kerja BMT Syirkah Muawanah Nahdlatul Ulama Pekalongan, tahap awal yang dilakukan pengajuan permohonan antara pihak nasabah dengan pihak BMT Syirkah Muawanah Nahdlatul Ulama Pekalongan. Dalam pelaksanaan pengajuan permohonan tersebut ditentukan juga tingkat harga. Besar kecilnya harga pembiayaan ditentukan oleh besar kecilnya jaminan yang disertakan oleh nasabah kepada BMT Syirkah Muawanah Nahdlatul Ulama Pekalongan. Agunan yang disertakan merupakan barang agunan yang telah dimiliki oleh pihak nasabah baik itu berupa tanah, tanah dan bangunan, kendaraan bermotor atau deposit.Hal tersebut berbeda dengan konsep murabahah dalam fiqh muamalah maupun konsep murabahah dalam perbankan syariah. Dimana besar kecilnya harga pembiayaan lebih ditentukan pada tingkat kebutuhan nasabah dengan dibuktikan dari seberapa besar pembiayaan untuk pembelian terhadap suatu barang yang riil atau nyata yang dibutuhkan oleh nasabah.

Demikian juga dalam penentuan margin keuntungan, sebagaimana telah dijelaskan mekanisme penentuan margin yang harus dibayar oleh nasabah kepada BMT, telah ditentukan diawal akad dan presentase margin telah ditentukan oleh pihak BMT sesuai dengan tingkan harga pembiayaan. Secara prinsip penentuan keuntungan diawal telah sesuai dengan ketentuan syariah akan tetapi persentase margin sesuai dengan tingkat harga pembiayaan yang dilakukan oleh BMT Syirkah Muawanah Nahdlatul Ulama Pekalongan menjadikan nasabah tidak bisa bebas melakukan negoisasi terkait dengan margin yang harus dibayar oleh nasabah kepada pihak BMT Syirkah Muawanah Nahdlatul Ulama Pekalongan. Karena menjadikan nasabah mautidak mau harus menerima dan menyetujui margin yang telah ditentukantersebut sedangkan dalam konsep fiqh bahwa kesepakatan keuntungan (margin)tidak boleh ditentukan secara sepihak, melainkan ditentukan oleh kesepakatanbersama antara nasabah dan BMT.

Uraian diatas dapat ditarik pemahaman bahwa akad tersebut nampaknya masih ada unsur-unsur yang belum 
tepat jika dikatakan sebagai akad murabahah. Kecenderungan yang ada adalah sebagai akad pinjam meminjam disertai tambahan.Dimana akad murabahah yang digunakanuntuk modal kerja padahal dalam ketentuan Fatwa Dewan Syariah NasionalNomor 04/DSNMUI/IV/2000 Tentang Murabahah ketentuan umum pada poinempat bank membeli barang yang di perlukan nasabah atas nama bank sendiri,dan pembelian ini harus sah dan bebas riba. Jadi ini menunjukan bahwa akadmurabahah dilakukan untuk seseorang yang membutuhkan barang bukanseseorang yang membutuhkan dana

2. Implikasi dari akad -akad yang ada pada pelaksanaan akad murabahah di BMT NU pekalongan

Akad/ perjanjian merupakan pangkal dari sebuah aktifitas, sehingga jika akad yang ada tidak jelas atau mengandung unsur keraguan, maka akan berakibat pada keraguan hukum dari kegiatan tersebut (ada unsur gharar) tidak dibenarkan. Hal ini nampak pada akad murabahah yang ada. Dari sisi kesesuaian antara kop dan isi perjanjian mengandung unsur ambiguitas. Sehingga belum jelas apakah akad ini murabahah atau akad/ perjanjian pinjam meminjam biasa. Apalagi jika rangkaian dari akad akadtersebut menjadi kontrak baku, maka menjadikan akad murabahah tidak sempurna. Konsekwensinya jika akadnya tidak sempurna, perjanjian tersebut merupakan perjanjian "pinjam meminjam" yang didalamnya terdapat klausul tambahan. Jika hal ini terjadi maka mengandung unsur riba dan niat untuk melakukan akad murabaha tidak terwujud (batal demi hukum).

3. Solusi dalam transaksi ini dapat dilakukan sekurangnya dua cara, pertama dengan mengembalikan syarat rukun murabahah secara syar'i. Yakni adanya penjual dan pembeli serta barang yang diharapkan serta sighat yang sesuai. Semisal BMT menyediakan/ menjual barang yang menjadi kebutuhan nasabah senilai yang disepakati baik dengan cara wakalah atau tidak. Jika dengan wakalah kepada nasabah, maka BMT harus memastikan ketersedian barang tersebut. Selanjutnya harga tersebut disampaikan kepada nasabah dan margin yang diharapkan. Adapun barang pihak nasabah murni hanya dijaminkan dan tidak perlu ada akad 
sewa menyewa. Sedangkan alternatif yang kedua adalah; pihak BMT bekerjasama dengan pihak nasabah untuk bersama-sama memiliki barang yang dibutuhkan oleh nasabah. Selanjutnya kedua belah pihak menyepakati harga. Pada giliran berikut Pihak II berkewajiban mengangsur kepemilikan barang tersebut sesuai porsi yang telah dimiliki. Dengan demikian akad yang dilakukan adalah Musyarakah.

\section{F. SIMPULAN}

1. Ada model Akad murabahah di BMT NU pekalongan yakni murabahah dengan wakalah dan murabahah yang tidak menggunakan wakalah. Pelaksanaan akad murabahah yang dilakukan oleh BMT NU Kota pekalongan cukup rumit dalam pembuatan akadnya. Paling tidak ada 4 akad yakni akad pinjaman murabahah, akad sewa menyewa, akad ijaroh dan perjanjian pinjaman.

2. Pada akad murabahah yang memakai wakalah pemilik barang (naabah), terdapat klausul akad yang kurang tepat (kurang syar'i), yakni adanya jual beli semu/ tipuan atau rekayasa.

3. Ada dua alternatif rekontruksi akad murabahah yakni mengembalikan syarat dan rukun akad sebagai mana ketentuan murabahah atau dengan cara musyarakah. 


\section{DAFTAR PUSTAKA}

Ahmad Azhar Basyir, "Asas-asas Hukum Muamalat", UI, Pres, Yogyakarta, 2000,

Bachsan Mustafa, Asas-asas Hukum Perdata, (Bandung: Armico, t.th.),

Bagya ASgung Prabowo, Aspek Hukum Murabaha Pada Perbankan Syariah, UII Pres, Yogyakarta, 2012

Gemala Dewi, Aspek-aspek Hukum dalam Perbankan di Indonesia, Citra Aditya Bhakti, Bandung, 2000,

Muhammad Syafi'i Antonio, bank Syariah: dari Teori dan Praktik, cet II (Jakarta: Gema Insani, 2007

Muhammad, Audit dan Pengawasan Syariah pada bank Syariah, Yogyakarta, UII Pres, .

Muhammad. Sistem dan Prosedur Operasional Bank Syariah. 2005. Jakarta : Raja Grafindo Persada.

Prof, Sugiyono, Metode Penelitian Kuantitatif, Kualitatif, dan RED, Bandung, Alfa Beta, 2010

Sekilas Perbankan syariah di Indonesia, artikel pada kolom informasi situs resmi Bank Indonesia, http://www.bi.go.id/web/id/Perbankan/perbankan +syariah/diakses 15 Februasri 2016

Soerdjono Soekamto dan sri mamudji, Karya Ilmiah Hukum Normatif Suatu Tinjauan singkat, jakarta: Raja Grafindo, 1994

Soerdjono Soekamto dan Sri Mamudji, Karya Ilmiah Hukum Normatif Suatu Tinjauan Singkat, jakarta: Raja Grafindo, 1994,

Soerjono Soekanto, Pengantar Penelitian Hukum, Jakarta, UI Press, 2010

Sri Mamudji, et.al. Metode Penulisan Dan Penelitian Hukum, Depok: Badan Penerbit Alumni, 2005 